\title{
Insulin signaling mediates previtellogenic development and enhances juvenile hormone-mediated vitellogenesis in a lepidopteran insect, Maruca vitrata
}

Md. Abdullah Al Baki ${ }^{1}$, Dae-Weon Lee ${ }^{2}$, Jin Kyo Jung ${ }^{3^{*}}$ and Yonggyun Kim ${ }^{1 *}$ (D)

\begin{abstract}
Background: Insulin/insulin-like growth peptide signaling (IIS) down-regulates hemolymph sugar level and facilitates larval growth in the soybean pod borer, Maruca vitrata. The objective of this study is to determine whether IIS of M. vitrata can mediate ovarian development of adult females.

Results: A pair of ovaries consists of 8 ovarioles, each of which is separated into distal germarium and proximal vitellarium in M. vitrata. In the germarium, oocyte development occurred with active mitotic activity which was visible by incorporating bromodeoxyribose uridine. Previtellogenic development and subsequent vitellogenesis began soon after adult emergence. They continued with increase of female age. Oocyte development was facilitated by upregulation of vitellogenin $(\mathrm{Vg})$ and $\mathrm{Vg}$ receptor $(\mathrm{VgR})$ gene expression. Larval diets significantly influenced on ovarian development of $M$. vitrata because oocyte development varied with pupal size derived from larvae treated with different nutritional diets. Its ovarian development was dependent on endocrine signal(s) from the head because decapitation soon after adult emergence prevented oogenesis and subsequent vitellogenesis along with marked reduction of $\mathrm{Vg}$ and $\mathrm{VgR}$ expression. Topical application of juvenile hormone $(\mathrm{JH})$ significantly recovered its ovarian development whereas farnesoic acid (a precursor of JH biosynthesis) or 20-hydroxyecdysone treatment did not. JH stimulated vitellogenesis and choriogenesis, but not previtellogenic development. In contrast, insulin injection to decapitated females stimulated oocyte differentiation and vitellogenesis along with increase of $\mathrm{V} g$ and $V g R$ expression. To further analyze the effect of insulin on ovarian development, expression of four IIS components (InR, FOXO, Akt, and TOR) genes was manipulated by RNA interference. Hemocoelic injection of gene-specific double stranded RNAs significantly reduced their target gene mRNA levels and interfered with ovarian development. An addition of insulin to $\mathrm{JH}$ treatment against decapitated females enhanced the gonadotropic effect of $\mathrm{JH}$ by stimulating oogenesis.
\end{abstract}

Conclusions: IIS plays crucial role in mediating previtellogenic development of M. vitrata in response to nutrient signal. It also enhances the gonadotropic effect of JH II on vitellogenesis.

Keywords: Insulin-like peptide, Reproduction, Oocyte, Vitellogenesis, Maruca vitrata

\footnotetext{
* Correspondence: jungjk@korea.kr; hosanna@anu.ac.kr

${ }^{3}$ Division of Crop Cultivation and Environment Research, Department of

Central Area Crop Science, National Institute of Crop Science, Rural

Development Administration, Suwon 16429, Korea

'Department of Plant Medicals, Andong National University, Andong 36729,

Korea

Full list of author information is available at the end of the article
}

(c) The Author(s). 2019 Open Access This article is distributed under the terms of the Creative Commons Attribution 4.0 International License (http://creativecommons.org/licenses/by/4.0/), which permits unrestricted use, distribution, and reproduction in any medium, provided you give appropriate credit to the original author(s) and the source, provide a link to the Creative Commons license, and indicate if changes were made. The Creative Commons Public Domain Dedication waiver (http://creativecommons.org/publicdomain/zero/1.0/) applies to the data made available in this article, unless otherwise stated. 


\section{Background}

High reproductive potential is a biological character of insects [1]. Social insects such as honey bee and termite queens are well known to have a huge number of egg production and subsequent oviposition [2]. Egg production of female insects is a sequential process consisting of previtellogenic development, vitellogenesis, and choriogenesis $[3,4]$. Previtellogenic development represents the formation of oocytes from oogonial stem cells by mitosis and meiosis. It occurs in the distal part of each ovariole [5]. Vitellogenesis is the process of accumulating vitellogenin $(\mathrm{Vg})$ and other biomaterials into growing oocytes [6, 7]. After oocytes are fully grown, they are coated with chorion by follicular epithelium to become "eggs" in the proximal part of ovarioles [8]. These eggs are then ovulated to oviducts and fertilized just before oviposition.

Different endocrine signals are associated with ovarian development in insects [9]. Juvenile hormone (JH) is a sesquiterpenoid that mediates a status quo effect during immature stage to prevent precocious metamorphosis $[10,11]$. However, in adults, it stimulates ovarian development as gonadotropin in various insects [12-14]. JH directly stimulates $\mathrm{Vg}$ biosynthesis in Manduca sexta and Locusta migratoria $[15,16]$. In mosquito females, it has endocrine action of 20-hydroxyecdysone (20E) [17, 18]. JH usually facilitates Vg uptake of growing oocytes by inducing follicular patency [19-21]. Thus, any inhibition of $\mathrm{JH}$ action can lead to severe impairment of ovarian development.

Insulin-like peptides (ILPs) are known to mediate ovarian development in some insects [22]. In Drosophila, ILPs can stimulate oogonial proliferation to produce oocytes in the stem cell niche located in the germarium of the distal ovariole [23]. Nutrient signal derived from reserves accumulated during larval period stimulates the brain to produce specific ILP(s) [24, 25]. Like vertebrate relaxin, the produced ILP stimulates ovarian development through a common insulin receptor $(\operatorname{InR})$ and initiates insulin/insulin-like growth factor signal (IIS) which is highly conserved among animals [26]. Especially, four IIS components (InR, serine-threonine protein kinase (Akt), Forkhead Box O (FOXO), and target of rapamycin (TOR)) have been assessed in physiological functions in controlling hemolymph sugar level and larval development $[27,28]$.

The legume pod borer, Maruca vitrata (Lepidoptera: Crambidae), is distributed in subtropical and tropical regions. It damages several leguminous crops with losses in the range of $20-80 \%$ [29]. Economic damage caused by $M$. vitrata may be explained by its high fecundity. $M$. vitrata is known to lay a lot of eggs (about 500 eggs per female), causing outbreaks under favorable conditions. M. vitrata females contain matured eggs before mating and oviposit soon after mating in the presence of stimulant from host floral volatiles [30]. Fecundity is one of the characters used by biologists to investigate individual fitness. It may greatly vary depending on the species and its life cycle [31]. It is also affected by a series of abiotic (e.g., temperature) and biotic (e.g., nutritional status, mating status, and age) parameters. It has been shown that fecundity is positively correlated with the number of ovarioles containing oocytes [32]. Thus, the high reproductive potential of $M$. vitrata can be understood through physiological analysis of ovarian development.

This study analyzed ovarian development of $M$. vitrata with respect to endocrine signals. Its ovarian development is known to be correlated with nutrients reserved during larval stage [33]. Thus, physiological role of IIS in its adult reproduction was investigated. This study also tested a functional synergism of IIS with $\mathrm{JH}$ signal in ovarian development of $M$. vitrata.

\section{Results \\ Ovarian development of $M$. vitrata females}

At 3 days of emergence, both ovaries of virgin females were well developed in size (Inset figure of Fig. 1a). Each ovary contained four ovarioles. Each ovariole was divided into three parts: previtellogenic (PV), vitellogenic (VT), and chorionated (CH) eggs (Fig. 1a). PV contained oocytes before vitellogenesis, in which oocytes were uniform in size. VT contained oocytes under vitellogenesis, in which oocytes increased in size along with ovariole to the proximal region. $\mathrm{CH}$ contained oocytes covered with chorion.

Distal region of the ovariole contained cells before oocyte differentiation. Oocytes were visible in previtellogenic region and surrounded by follicular epithelium (Fig. 1b). Nurse cells were neighboring to oocytes, indicating polytrophic ovarioles of $M$. vitrata. In vitellogenic region, oocytes grew in size along with increase of follicular epithelium area.

At the most distal region of each ovariole, undifferentiated cells were highly detected by BrdU staining, indicating active cell division (Additional file 1: Figure S1A). Subsequently, a series of cell division with increasing number of nuclei (see DAPI staining) was detected (Additional file 1: Figure S1B). At the end of this cell division, a follicle containing nurse cells and an oocyte surrounded by follicular epithelium were observed (Additional file 1: Figure S1C).

\section{Expression profiles of $\mathbf{v g}$ and $\mathrm{VgR}$ in $M$. vitrata females}

To analyze vitellogenesis of $M$. vitrata, vitellogenin (Vg) and $\mathrm{Vg}$ receptor $(\mathrm{VgR})$ genes were identified and their expression levels were monitored along with female development (Fig. 2). Vg protein was detected in female adults, but not detected in larval hemolymph or male 
A

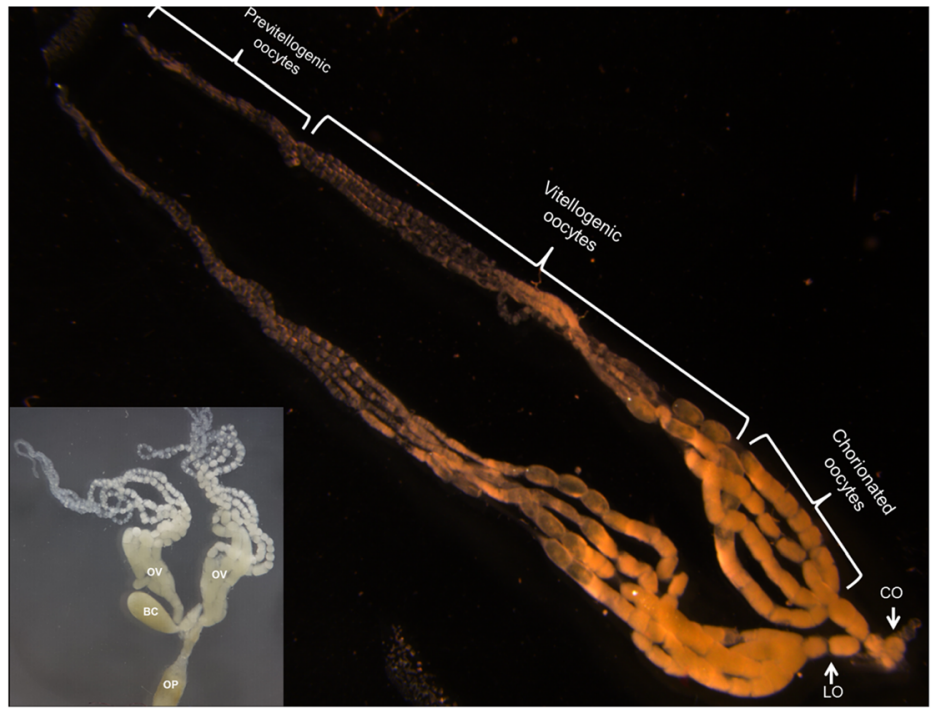

B

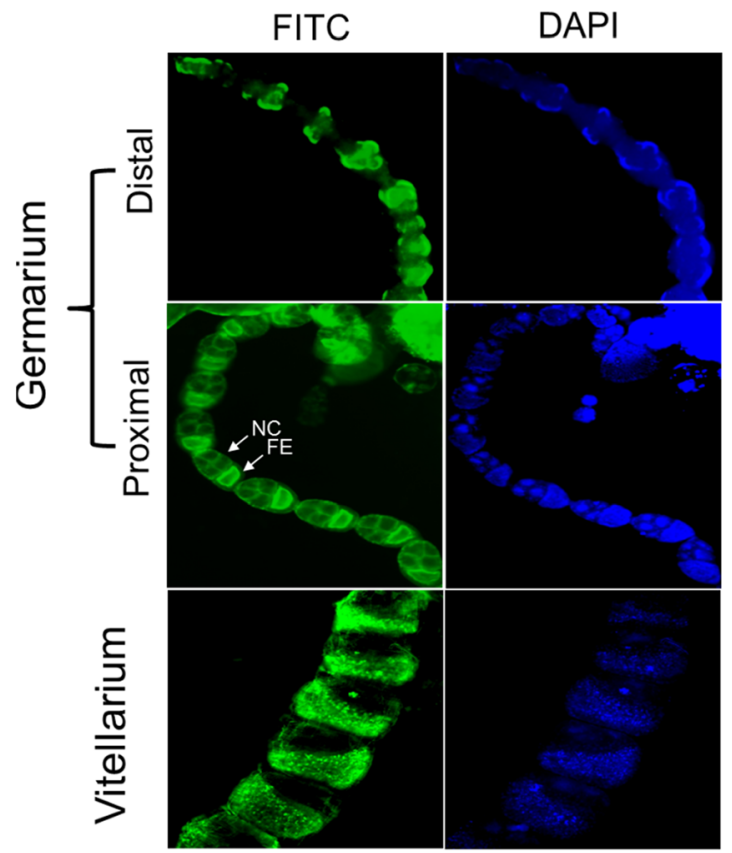

Fig. 1 Ovary structure of M. vitrata females. a Total ovary (OV) structure of 5 days old female. A pair of ovaries is extended from common oviduct (CO) via lateral oviduct (LO). In each of ovariole, oocyte development is subdivided into previtellogenic oocyte, vitellogenic oocyte, and chorionated oocyte under a stereomicroscope. Inset figure shows bursa copulatrix (BC) and ovipositor (OP) near ovaries. b Comparison of oocyte development between germarium and vitellarium. In germarium, oocytes are invisible in distal region. However, they are distinct in the proximal region along development of nurse cell (NC) and follicular epithelium (FE). In vitellarium, oocyte increases with increase of FE area. F-actin filament is specifically recognized by FTT-tagged phalloidin (green) while nucleus is stained with DAPI (blue). Cells are observed under a fluorescence microscope at $200 \times$ magnification

adult in SDS-PAGE (Fig. 2a). Its apparent size on the protein gel was approximately $200 \mathrm{kDa}$. LC-tandem MS analysis revealed that the $\mathrm{Vg}$ band was highly matched to other lepidopteran $\mathrm{Vg}$ proteins (Fig. 2b). $\mathrm{Vg}$ and $\mathrm{VgR}$ genes were predicted (Additional file 2: Figure S2, Additional file 3: Figure S3) from a transcriptome of $M$. vitrata (GenBank accession numbers:
MG799570 for Vg and MG799569 for VgR). Open reading frame (ORF) of $\mathrm{Vg}$ encoded 1777 amino acids with molecular weight of $202.06 \mathrm{kDa}$ and $\mathrm{pI}$ at 8.27 . VgR ORF encoded 1798 amino acids with molecular weight of $198.28 \mathrm{kDa}$ and $\mathrm{pI}$ at 4.98. RT-PCR analysis indicated that $V g$ and $V g R$ were expressed in females. Their expression levels increased with age (Fig. 2c). 

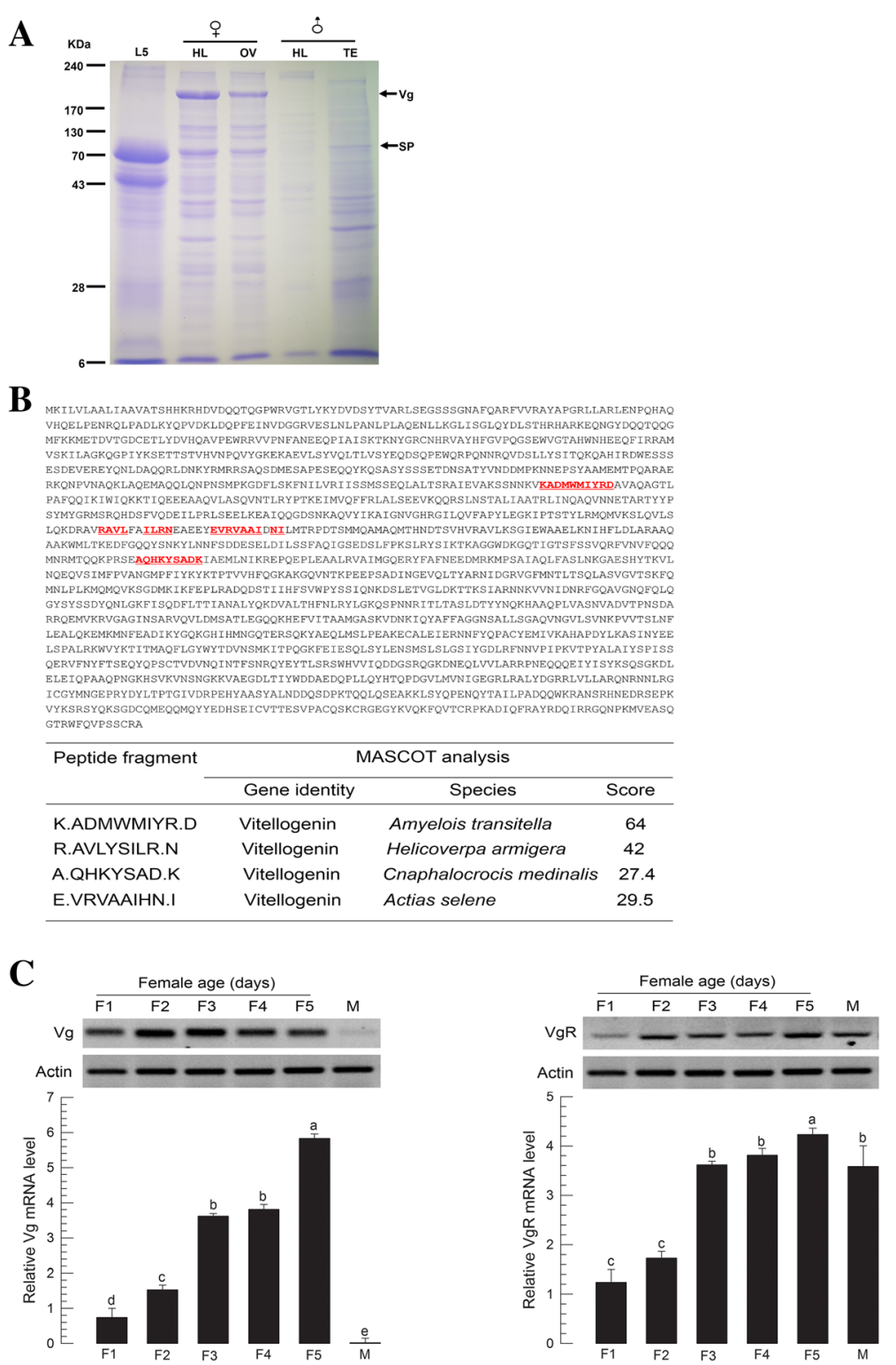

Fig. 2 Identification and expression profile of vitellogenin $(\mathrm{Vg})$ and vitellogenin receptor ( $\mathrm{VgR}$ ) of M. vitrata. a $\mathrm{Vg}$ on 10\% SDS-PAGE. Vg protein was identified in 5 days old adult female hemolymph (HL) and ovary (OV), but not in male $\mathrm{HL}$, testis (TE), or $L 5$ larvae. $L 5$ larval $H L$ contained a large amount of storage protein (SP). $\mathbf{b}$ LC-MS/MS analysis of $\mathrm{Vg}$ protein band and its MASCOT prediction. The sequence of $M$. vitrata Vg (GenBank accession number: MG799570) contains fragments identified by LC-MS/MS. c Expression analyses of Vg and VgR in females at different ages (1-5 days after emergence) and males ( 5 days old after emergence) using RT-PCR (gel picture) and RT-qPCR (graph). All treatments in RT-qPCR were independently replicated three times. $\beta$-Actin expression was used as reference in RT-qPCR to normalize target gene expression level. Different letters above standard deviation bars indicate significant difference among means at Type I error $=0.05$ (LSD test)

$V g$ expression was female-specific while $V g R$ was expressed in both sexes.

\section{Influence of larval diet on adult ovarian development}

In virgin females, total number of oocytes increased with adult age until 7 days old (Fig. 3a). The increase in the number of oocytes was accompanied by an increase of the number of PV oocytes. To determine whether oocyte development of adult females was affected by larval diet, different nutritional diets were fed to larvae and oocyte development was analyzed for the resulting female adults ( 5 days old). Various diet treatments produced different body weights of pupae. Total numbers of oocytes in adult females were increased with increase of pupal weights (Fig. 3b). There was significant difference $(P<$ $0.05)$ in the number of previtellogenic oocytes among larval diet treatments. To see more detailed correlation between larval diets and adult oocyte development, 
A

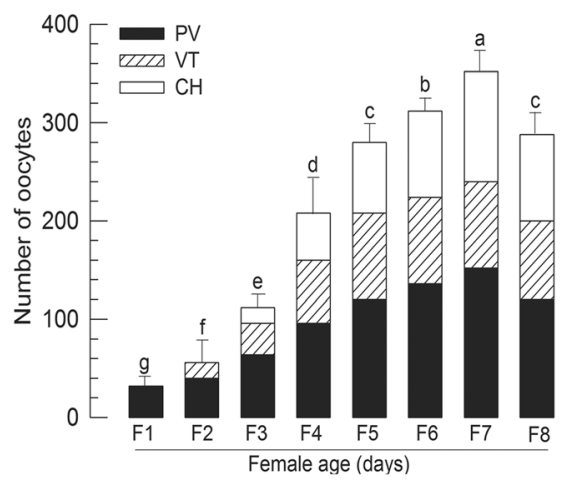

C

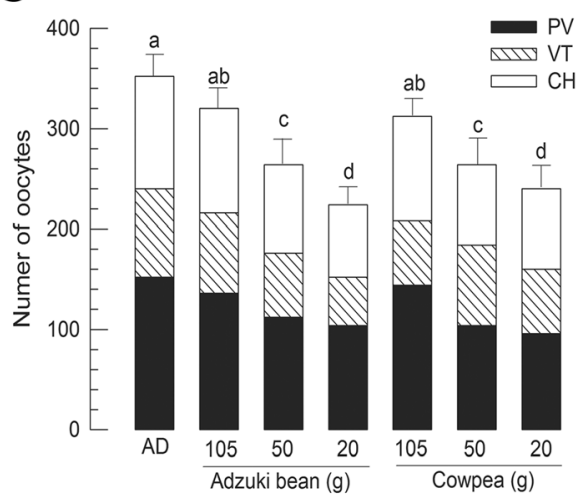

B

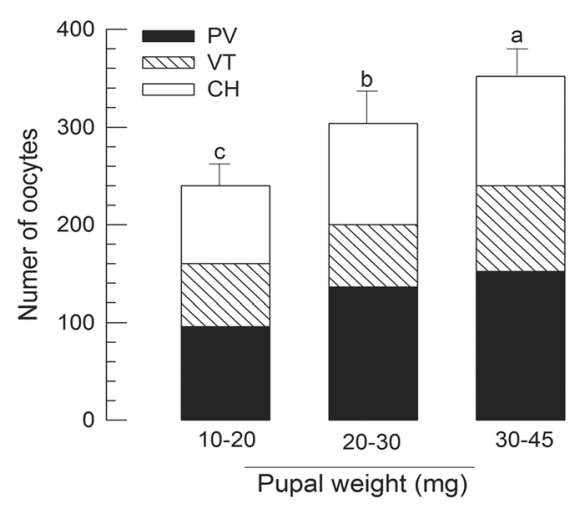

D

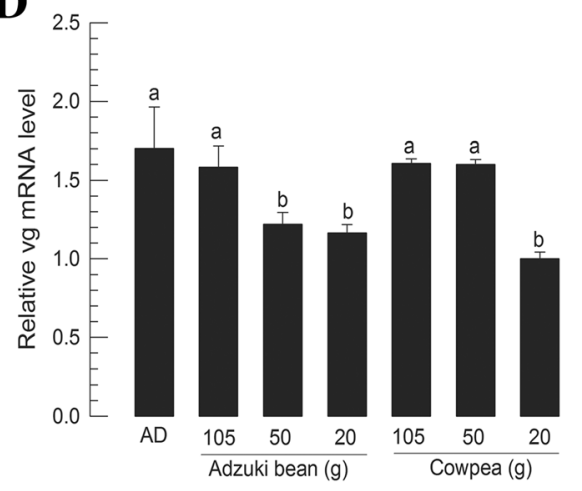

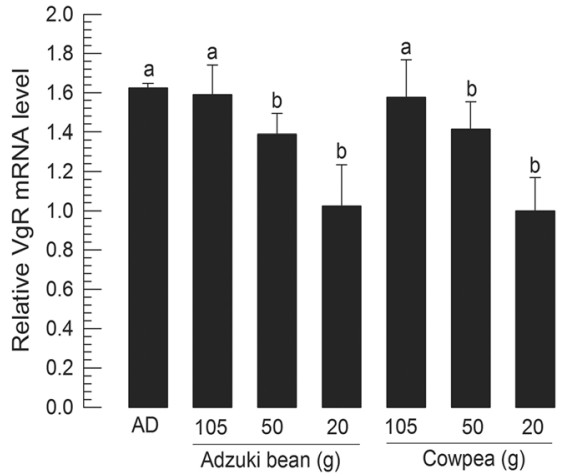

Fig. 3 Effect of larval nutrients on adult ovarian development of M. vitrata. a Oocyte development according to female age. Ovarioles were separated from different aged females (1-8 days after emergence) to count the number of previtellogenic oocytes (PV), vitellogenic oocytes (VT), and chorionated $(\mathrm{CH})$ oocytes. For each age treatment, 10 females were analyzed. $\mathbf{b}$ Influence of pupal weight on ovarian development. Ten females ( 5 days old after emergence) were randomly collected from three body weight pupal groups and assessed in oocyte development. c Effect of larval diets on oocyte development. A standard artificial diet ('AD'), three adzuki bean diets in different nutritional amounts, and three cowpea diets in different nutritional amounts were assessed for this analysis. For each diet treatment, 10 females ( 5 days old after emergence) were randomly selected and their oocyte development was assessed. $\mathbf{d}$ Expression levels of $\mathrm{Vg}$ and $\mathrm{V} g \mathrm{R}$ in adults developed from larvae treated with different diets. Expression levels of these two gene were quantified by RT-qPCR in 5 days old females. All treatments were independently replicated three times. $\beta$-Actin expression was used as reference gene of RT-qPCR to normalize target gene expression level. Different letters above standard deviation bars indicate significant difference among means at Type I error $=0.05$ (LSD test)

numbers of oocytes formed in adult females were compared among larval diets (Fig. 3c). The nutritional quality of larval diet was directly related to oocyte development of adult females. Again, larval diets influenced oogenesis because the number of previtellogenic oocytes was different according to diet quality. In addition, larval diet quality influenced Vg production. Moreover, expression levels of $V g$ and $V g R$ in adult females were significantly $(P<0.05)$ different among different groups of larval diets (Fig. 3d). 
Effect of decapitation and $\mathrm{JH}$ on ovarian development To understand endocrine signal(s) from the brain to control ovarian development, decapitation was applied to teneral female adults (Fig. 4). Soon after adult emergence $(<4 \mathrm{~h})$, females were decapitated and reared at $25^{\circ} \mathrm{C}$ for 5 days. Decapitated females did not produce any vitellogenic oocytes. They had much lower number of previtellogenic oocytes compared to control ones. Different developmental hormones were then applied to these decapitated female adults to determine gonadotropin of M. vitrata (Fig. 4a). Application of $\mathrm{JHs}$ stimulated egg production. However, treatment with $20 \mathrm{E}$ or $\mathrm{JH}$ precursor (farnesoic acid: FA) did not rescue the decapitation effect on ovarian development. Among JHs, JH II was significantly $(P<$ 0.05 ) superior to $\mathrm{JH}$ I and JH III in egg production. Although $\mathrm{JH}$ treatment increased the number of vitellogenic oocytes, it did not increase the number of previtellogenic oocytes.
The effect of JH on ovarian development was also confirmed by analyzing $\mathrm{Vg}$ protein level in female hemolymph (Fig. 4b). Vg protein was detected in females from three $\mathrm{JH}$ (JH I to III) treatment groups, but not in the control, FA, or 20E treatment group. To support this protein expression result, mRNA levels of $V g$ and $V g R$ were analyzed by RT-qPCR (Fig. 4c). Expression levels of both genes were highly induced by $\mathrm{JH}$ treatments, but not by FA and 20E treatments, compared to the level of acetone-treated decapitated females.

\section{Influence of IIS on ovarian development}

To explore previtellogenic development stimulated by endocrine signal, insulin signaling was assessed by adding porcine insulin to decapitated females (Fig. 5). Porcine insulin is known to be effective in regulating larval growth and hemolymph sugar level of $M$. vitrata [27, 34]. In the present study, the addition of porcine insulin significantly $\quad(P<0.05) \quad$ rescued $\quad$ previtellogenic
A

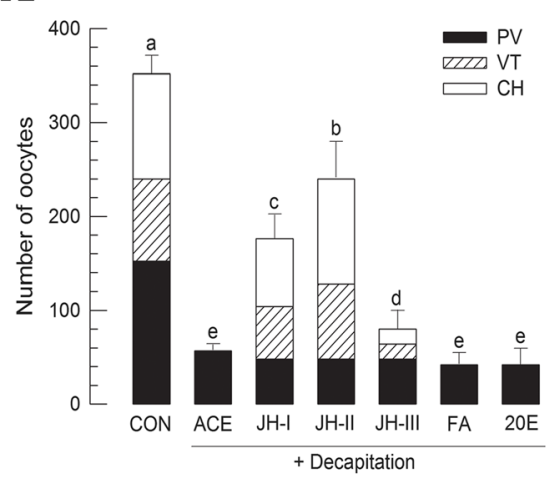

C

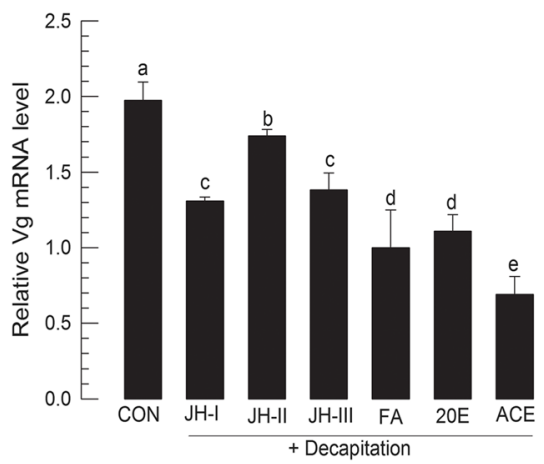

B

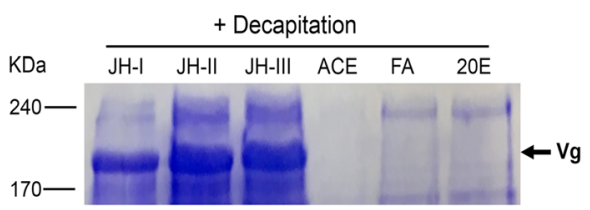

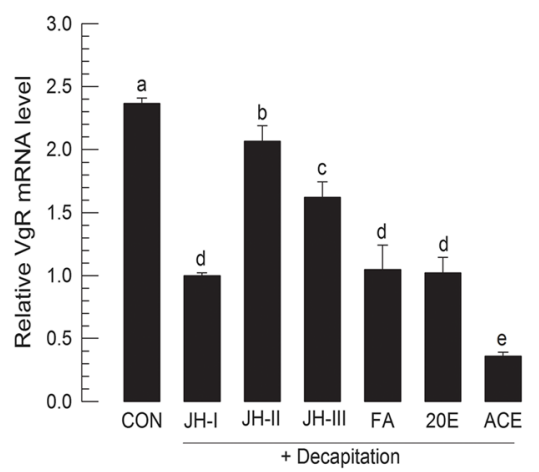

Fig. 4 Effect of juvenile hormone $(\mathrm{JH})$ on ovarian development of $M$. vitrata. a Effect of decapitation and subsequent hormonal treatment on oocyte development. Decapitation was performed in teneral female adults soon after emergence $(<12 \mathrm{~h})$. Hormones were injected into decapitated females in a concentration of $1 \mu \mathrm{g}$ per female using a microsyringe. Three $\mathrm{JHs}(\mathrm{JH} \mathrm{I}, \mathrm{JH} \mathrm{II}$, and JH III), farnesoic acid (FA), and 20-hydroxyecdysone (20E) were assessed. Acetone ('ACE') was used as a control in decapitation treatment. 'CON' represents females without decapitation treatment. After 5 days at $25^{\circ} \mathrm{C}$, 10 females in each treatment were assessed for oocyte development. b Vitellogenin ( Vg) production analysis using 10\% SDS-PAGE. Hemolymph was collected from 5 days old females treated with different hormones. $\mathbf{c}$ Expression levels of $V g$ and $V g R$ in adults treated with different hormones. Expression levels of these two genes were quantified by RT-qPCR in 5 days old females. All treatments were independently replicated three times. $\beta$ Actin expression was used as a reference in RT-qPCR to normalize target gene expression level. Different letters above standard deviation bars indicate significant difference among means at Type I error $=0.05$ (LSD test) 
A
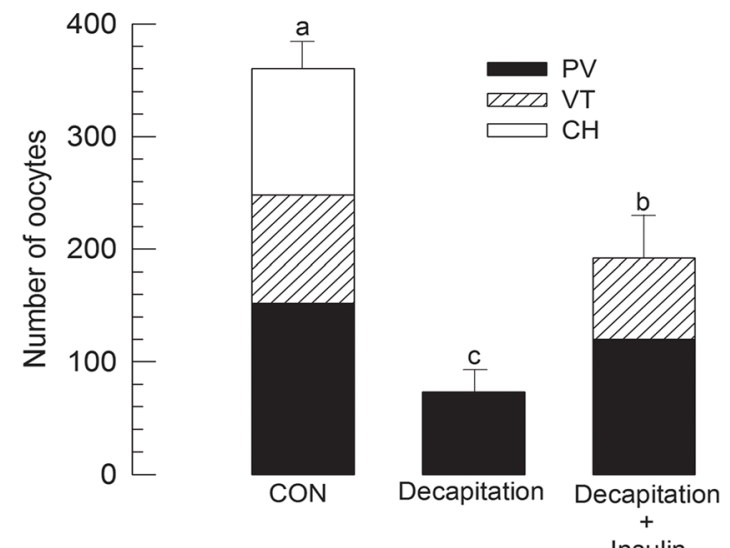

B

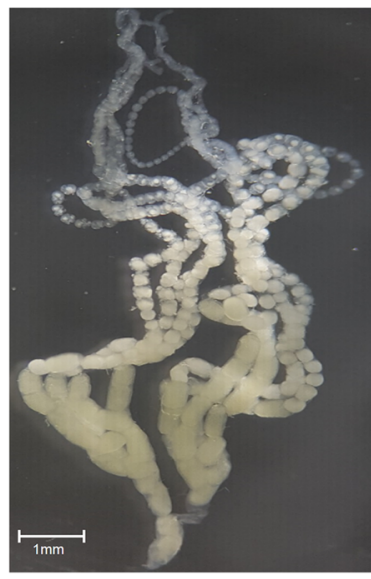

CON

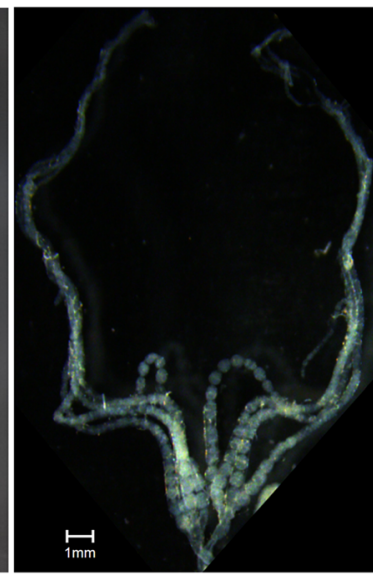

Decapitation

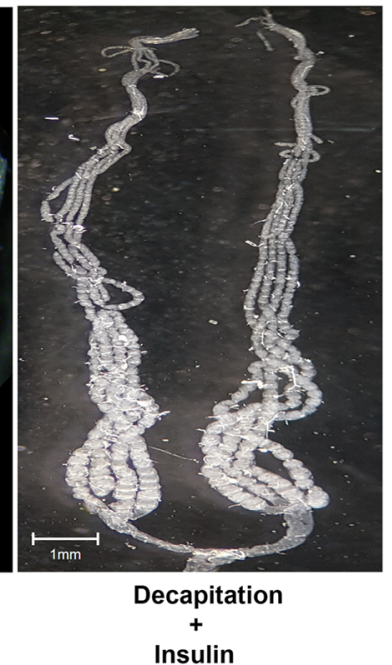

Insulin

Fig. 5 Effect of insulin on ovarian development of M. vitrata. a Effect of decapitation and subsequent insulin treatment on oocyte development. Decapitation was performed in teneral female adults soon after emergence $(<12 \mathrm{~h})$. Porcine insulin was injected into decapitated females in a concentration of $1 \mu \mathrm{g}$ per female using a microsyringe. 'CON' represents females without decapitation treatment. After 5 days at $25^{\circ} \mathrm{C}, 10$ females in each treatment were assessed for oocyte development. Different letters above standard deviation bars indicate significant difference among means at Type I error $=0.05$ (LSD test). $\mathbf{b}$ Photos showing ovaries from females treated with decapitation or insulin addition compared to untreated (CON) female ovary. Scale bar represents $1 \mathrm{~mm}$

development (Fig. 5a). The addition of porcine insulin also stimulated vitellogenesis. However, it did not induce choriogenesis (Fig. 5b).

To further investigate the effect of insulin on oocyte differentiation, expression levels of four IIS components (InR, FOXO, Akt, and TOR) were altered by RNAi treatment (Fig. 6). Injecting dsRNAs specific to IIS component genes significantly $(P<0.05)$ suppressed their gene expression levels (Fig. 6a). RNAi efficiencies for all four IIS components ranged from 68 to $90 \%$. Under these RNAi conditions, ovarian development was significantly $(P<0.05)$ reduced (Fig. $6 \mathrm{~b})$. These RNAi treatments also suppressed gene expression levels of $V g$ and $V g R$ (Fig. 6c), resulting in hypotrophied ovaries (Fig. 6d).

\section{Cooperative effect of insulin and $\mathrm{JH}$ on ovarian development}

$\mathrm{JH}$ stimulated vitellogenesis, but not oocyte differentiation while IIS stimulated both oogenesis and vitellogenesis, suggesting that these two endocrine signals might be cooperative to produce fully grown oocytes. The hormonal mixture effect of $\mathrm{JH}$ and insulin on ovarian development was analyzed (Fig. 7). JH II was highly effective in inducing ovarian development. However, ovarian development induced by $\mathrm{JH}$ II was not as high as, but its mediation was not enough compared that in control females (Fig. 7a). Addition of insulin significantly enhanced the effect of $\mathrm{JH}$ on ovarian development. Decapitated females could develop fully grown oocytes with co-injection of JH II and insulin, exhibiting similar ovarian development like control females (Fig. 7b). 
A

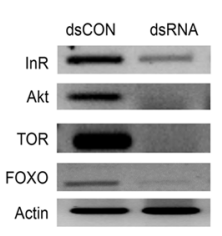

B

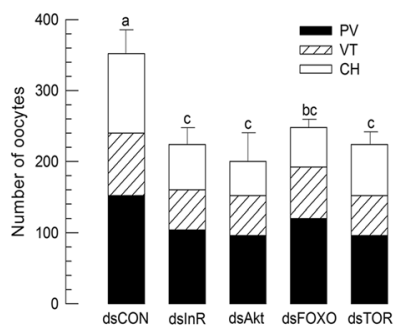

C

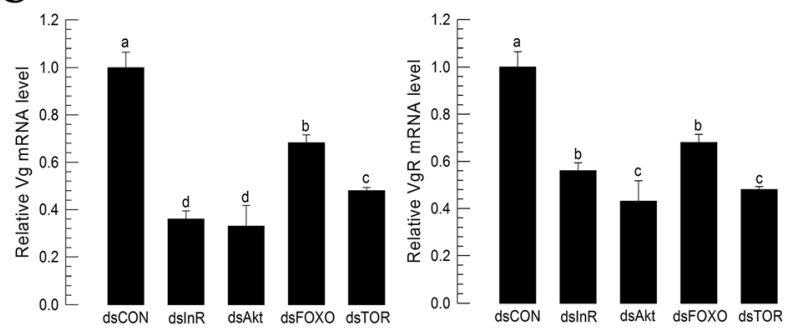

D

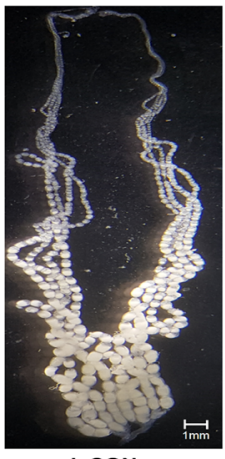

dsCON

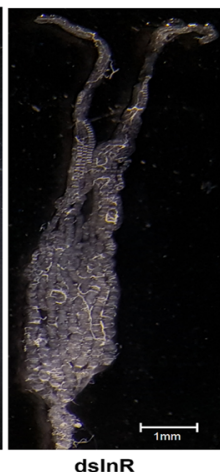

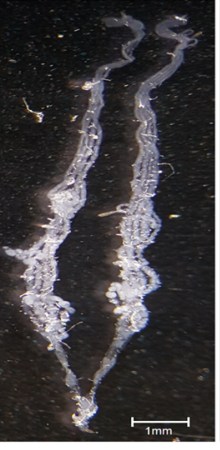

dsAkt

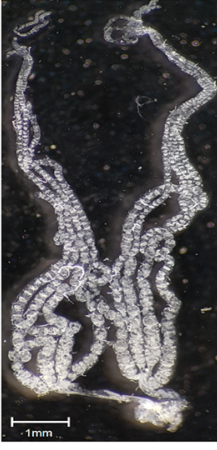

dsFOXO

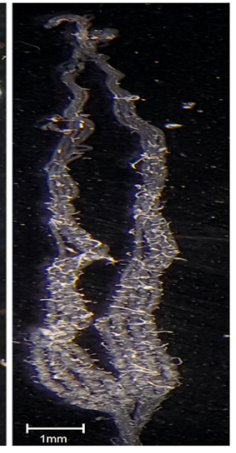

dsTOR

Fig. 6 Influence of insulin-like peptide/IGF signaling (IIS) on ovarian development of M. vitrata. a RNA interference (RNAi) using dsRNAs specific to insulin receptor (InR), serine/threonine-protein kinase (Akt), target of rapamycin (TOR), and Forkhead box protein O (FOXO). dsRNA (1 $\mu \mathrm{g})$ specific to each gene was injected to 5 days old pupae (pharate adult stage). Newly emerged adults were reared with 10\% sugar until 5 th day. Changes in mRNA levels were monitored by RT-qPCR using $\beta$-actin gene expression as reference to normalize target gene expression level. Control RNAi (dsCON) used a viral gene, CpBV302, by injecting its dsRNA at the same dose. All treatments were independently replicated three times. Different letters above standard deviation bars indicate significant difference among means at Type I error $=0.05$ (LSD test). $\mathbf{b}$ RNAi effect of IIS components (InR, Akt, FOXO or TOR) on oocyte development. dsInR, dsAkt, dsFOXO, and dsTOR represent specific respective dsRNAs. Ovarioles were separated from 5 days old females to count the number of previtellogenic oocytes (PV), vitellogenic oocytes (VT), and chorionated (CH) oocytes. For each treatment group, 10 females were analyzed. $\mathbf{c}$ Expression levels of $\mathrm{Vg}$ and $\mathrm{Vg} R$ in adults treated with different dsRNAs. Expression levels of these two genes were quantified by RT-qPCR in 5 days old females. All treatments were independently replicated three times. $\beta$-Actin expression was used as reference in RTqPCR to normalize target gene expression level. Different letters above standard deviation bars indicate significant difference among means at Type I error $=0.05$ (LSD test). $\mathbf{d}$ Photos showing ovaries from females treated with different dsRNAs. Scale bar represents $1 \mathrm{~mm}$

\section{Discussion}

This study investigated the influence of endocrine signals on $M$. vitrata egg development. Insect female reproduction is controlled by $\mathrm{JH}$ and ecdysteroids along with nutritional signal [9]. The nutritional signal is mediated by ILPs in egg development of Drosophila [26]. 


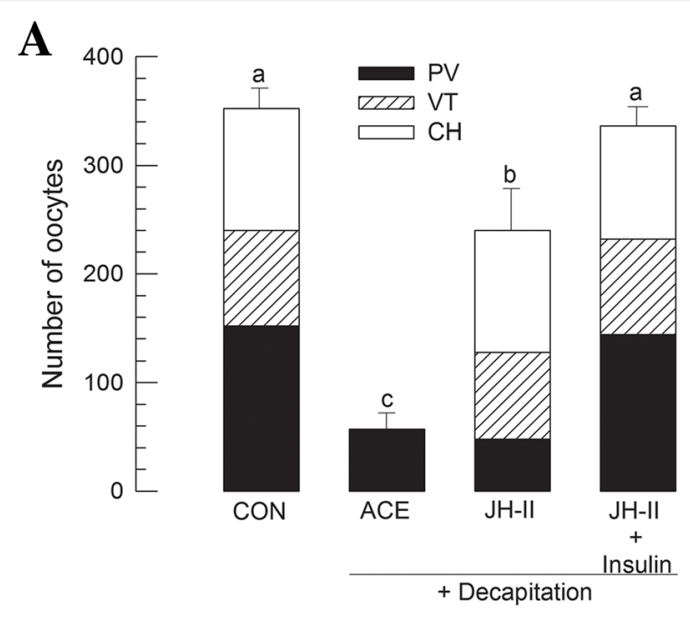

\section{B}

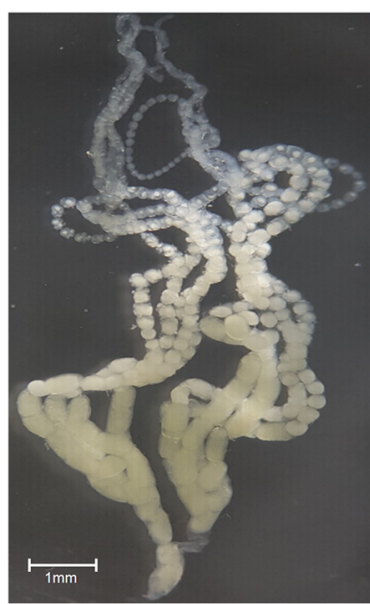

CON

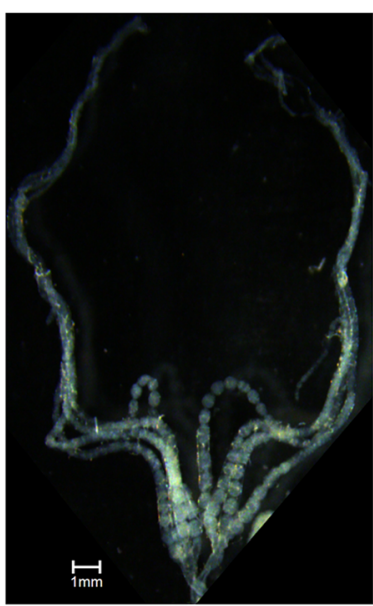

Decapitation

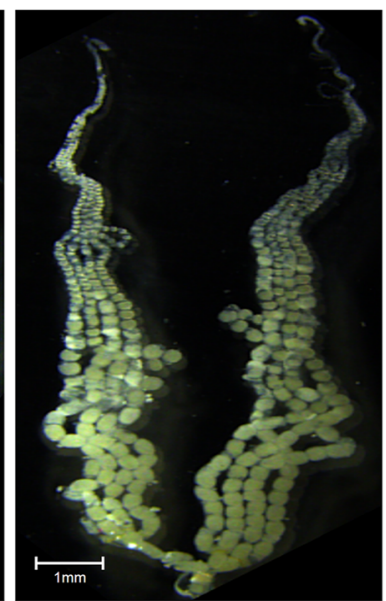

Decapitation + JH II + Insulin

Fig. 7 Synergistic effect of insulin and $\mathrm{JH}$ II on ovarian development of $\mathbf{M}$. vitrata. a Effect of decapitation and subsequent hormone treatment on oocyte development. Decapitation was performed in teneral female adults soon after emergence $(<12 \mathrm{~h})$. JH II or porcine insulin was injected into decapitated females at $1 \mu \mathrm{g}$ per female using a microsyringe. 'CON' represents females without decapitation treatment. After 5 days at $25^{\circ} \mathrm{C}$, 10 females in each treatment were assessed for oocyte development. Different letters above standard deviation bars indicate significant difference among means at Type I error $=0.05$ (LSD test). $\mathbf{b}$ Photos showing ovaries from females treated with decapitation or hormone addition compared to untreated (CON) female ovary. Scale bar represents $1 \mathrm{~mm}$

According to this general physiological pattern, egg development of $M$. vitrata would also exhibit high dependency on endocrine factors.

There are two ovaries in $M$. vitrata, with each ovary containing four ovarioles. The number of ovarioles per ovary is commonly species-specific. It has great variations across insects, ranging from less than five per ovary in some flies to hundreds per ovary in some grasshoppers [3]. Microscopic analysis of $M$. vitrata oocyte development using fluorescence dyes indicated that its ovariole could be divided into germarium and vitellarium, in which germarium was characterized by previtellogenic oocytes while vitellarium was filled with growing matured oocytes. Like other holometamorphic insects, the ovariole of $M$. vitrata is polytrophic because each oocyte is linked with nurse cells and surrounded by follicular epithelium. In
Drosophila, oocyte development occurs in germarium from germline stem cells by four cycles of asymmetric cell divisions, in which 15 cells become nurse cells while the remaining cells become oocytes [23]. In the germarium of $M$. vitrata ovariole, cell divisions were detected by BrdU staining and dividing nuclei were observed from DAPI staining, indicating its oocyte development. At the terminal germarium, the oocyte was distinct from nurse cells and surrounded by follicular epithelium. After that, oocytes grew in size probably by accumulating nutrients including Vg from hemolymph. Finally, fully grown oocytes at the proximal ovariole were coated with chorion to be ovulated into the oviduct before oviposition. This is the first detailed analysis of egg development of $M$. vitrata by examining oocyte development and subsequent developmental stages. 
$V g$ expression of $M$. vitrata was dependent on larval nutrients, JH, and IIS. Vg protein was specifically detected in female hemolymph of $M$. vitrata. LC-MS/MS analysis of $\mathrm{Vg}$ band showed that it was highly matched with other lepidopteran Vg proteins. Its apparent size (approximately $200 \mathrm{kDa}$ ) on protein gel was similar to the predicted molecular size $(202 \mathrm{kDa})$ based on $\mathrm{Vg}$ gene. This study also identified a VgR of M. vitrata. VgR is a member of the low density lipoprotein receptor family that can transport vitellogenin into ovaries to promote ovarian growth and embryonic development [7]. In insects, the only widely accepted ligand of VgR is Vg [35]. During vitellogenesis, Vg is synthesized in the fat body, released into hemolymph [16], and uptaken through VgR of growing oocytes to serve as a nutrient reserve for developing embryo [7]. $\mathrm{Vg}$ and $V g R$ gene expression levels were altered by larval nutrition quality in $M$. vitrata. The effect of larval diet on adult reproduction in $M$. vitrata has been reported in a previous study [36], where different larval diets have resulted in different adult fecundity (109.2 vs. 174.2 eggs laid by each female). In another lepidopteran insect (Spodoptera exigua), $V g$ and $V g R$ expression levels are also markedly modulated by host nutrients [37]. This can be interpreted by mediation of IIS under nutrient storage in the fat body. In Drosophila, fat body can sense amino acids and send a nutritional signal called fat body-derived signal [38]. In response to the fat body-derived signal, insulin-producing cells (IPCs) in the brain produce ILPs to directly or indirectly activate $\mathrm{Vg}$ production [39]. JH has been regarded as a main gonadotropin along with $20 \mathrm{E}$ and neuropeptides [40, 41]. However, different lepidopteran species vary in $\mathrm{JH}$ and $20 \mathrm{E}$ dependency according to different reproductive characteristics in terms of the onset of $\mathrm{Vg}$ synthesis [40, 42]. In type I insects (Bombyx mori [43], Antheraea yamamai [44], and Lymantria dispar [45-47]), Vg synthesis is mediated by 20E at the last larval or early pupal stage. In type II as seen in Plodia interpunctella [48], Vg synthesis is triggered by low 20E titers at pupal stage. In type III, Vg synthesis is independent to $20 \mathrm{E}$ as seen in $M$. sexta [15]. In type IV insects including Heliothis virescens [8, 49], Helicoverpa zea [50], Pieris brassicae [51], Nymphalis antiopa [52], Danaus plexippus [53], Vanessa cardui [54], D. chrysippus [55], Pseudaletia unipuncta [56], and Spodoptera frugiperda [57], Vg synthesis is mediated by $\mathrm{JH}$ at early adult stage. Thus, $M$. vitrata could be included in the last lepidopteran group because its $\mathrm{Vg}$ expression was dependent on $\mathrm{JH}$, but not on 20E. JH II was most effective in inducing $V g$ expression in $M$. vitrata. Most lepidopteran species in general use JH I and JH II [58]. Similar result for S. exigua has been obtained in our previous report showing that both JH I and $\mathrm{JH}$ II can inhibit metamorphosis of pupae when they are applied to young pupae whereas JH III cannot [59]. In comparison, the hemolymph of $S$. litura, a close taxonomical species to $S$. exigua, has only JH II [60]. These results suggest that endogenous $\mathrm{JH}$ of $M$. vitrata is $\mathrm{JH}$ II which is a main gonadotropin.

$\mathrm{JH}$ stimulated vitellogenesis, but not oogenesis, in $M$. vitrata. Oogenesis was markedly influenced by IIS under diet signal. In Drosophila, IIS regulates germline stem cell proliferation $[61,62]$ and triggers vitellogenesis from the fat body in response to nutritional signal [24, 25]. Thus, ovarian growth is arrested at the previtellogenic stage in Drosophila with mutant IIS components [63]. Chico (Drosophila gene corresponding to insulin receptor substrate) mutant flies display reduced proliferation of follicular stem cells. Their follicles fail to progress to the vitellogenic stage, even in the presence of abundant nutrients [61, 64]. In $M$. vitrata, all four RNAi treatments against IIS components prevented oocyte development, including oocyte differentiation and vitellogenesis. IIS role in stimulating oocyte development was further supported by the observation that addition of a porcine insulin to decapitated females significantly reversed the reduced development of oocytes in $M$. vitrata. Tu et al. [65] have shown that ILP indirectly influences $\mathrm{JH}$ biosynthesis through control of $\mathrm{JH}$ regulatory neuropeptides. Thus, ILP can have dual positive effect on egg development of $M$. vitrata by activating germline stem cell proliferation and indirectly activating $\mathrm{JH}$ synthesis. The dual effect of ILP on previtellogenic and vitellogenic developments suggests a cooperative effect of ILP on JH II because both oogenesis and vitellogenesis could be stimulated by these hormone treatments. Our current study showed that porcine insulin significantly enhanced the effect of JH II on oocyte development. In mosquitoes using $20 \mathrm{E}$ as a gonadotropin, ILPs also regulate $V g$ expression indirectly through the regulation of ecdysone synthesis after blood meal [66]. The functional relationship between JH/20E and ILP is well explained using model insects, in which $\mathrm{JH} / 20 \mathrm{E}$ via IIS stimulates $\mathrm{Vg}$ expression through derepression of FOXO by phosphorylation [67].

\section{Conclusions}

This study determined two endocrine signals of ILP and $\mathrm{JH}$ as gonadotropins of $M$. vitrata. These two endocrine signals cooperatively promoted egg development, in which ILP stimulated previtellogenic development by proliferation of germline stem cell in response to fat body-derived signal while $\mathrm{JH}$ mediated vitellogenesis by activating $\mathrm{Vg}$ expression.

\section{Methods}

\section{Insect rearing}

Rearing of $M$. vitrata followed the method described by Jung et al. [68]. 


\section{Chemicals}

For hormonal assays, JH I $\left(\mathrm{C}_{18} \mathrm{H}_{30} \mathrm{O}_{3}\right)$ and $\mathrm{JH}$ II $\left(\mathrm{C}_{17} \mathrm{H}_{28} \mathrm{O}_{3}\right)$ were purchased from Scitech (Praha, Czech) . JH III $\left(\mathrm{C}_{16} \mathrm{H}_{26} \mathrm{O}_{3}\right)$, porcine insulin $\left(\mathrm{C}_{254} \mathrm{H}_{377} \mathrm{~N}_{65} \mathrm{O}_{75} \mathrm{~S}_{6}\right)$, farnesoic acid (FA: $\mathrm{C}_{15} \mathrm{H}_{24} \mathrm{O}_{2}$ ), and 20-hydroxyecdysone (20E: $\mathrm{C}_{27} \mathrm{H}_{44} \mathrm{O}_{7}$ ) were purchased from Sigma-Aldrich Korea (Seoul, Korea). Acetone was purchased from Duksan Chemicals (Ansan, Korea).

For immunocytochemistry assays, bromodeoxyribose uridine (BrdU) and fluorescein isothiocyanate (FITC)tagged phalloidin were obtained from Sigma-Aldrich Korea. 4',6-diamidino-2-phenylindole (DAPI) was purchased from Thermo Fisher Scientific (Rockford, IL, USA)

\section{Analysis of ovarian development}

Virgin females (1-8 days old) were used. Ovary was dissected in $100 \mathrm{mM}$ phosphate-buffered saline (PBS, pH 7.4) under a stereomicroscope (Stemi SV11, Zeiss, Germany). Ovarioles were separated from the female body and transferred onto slide glass to make them straight. Previtellogenic oocytes were located at the distal region. They had no apparent size increase with well differentiation of nurse cells. Vitellogenic oocytes exhibited apparent size increase in oocytes presumably by accumulation of vitellogenin (Vg). Chorionic oocytes were characterized by chorion formation at the proximal region of ovarioles. Each treatment was replicated with three different females. Total oocyte number was calculated by multiplying the number of oocytes in each ovariole by eight due to the presence of eight ovarioles in a pair of ovaries.

\section{Analysis of larval nutrient on ovarian development in adults}

Based on a standard artificial diet ('AD'), six other diets were prepared by adding different amounts of main legume components (Additional file 4: Table S1). The resulting seven different diets were fed to L1 for the entire larval feeding period. Each treatment used 30 larvae. Newly molted pupae $(<12 \mathrm{~h})$ were weighed and virgin females at 5 days after emergence were dissected to assess ovarian development by counting oocytes. Randomly chosen 10 females were assessed in each diet treatment.

\section{Decapitation and hormonal treatment}

Newly emerged $M$. vitrata females were decapitated and used for hormonal analysis. For hormonal treatment, decapitated females were injected with $3 \mu \mathrm{L}$ of hormone or solvent with a microsyringe (Hamilton, Reno, NV, USA). JH I, JH II, JH III, FA, and 20E (in 100\% ethanol) were dissolved in acetone (concentration in $\mathrm{mg} / \mathrm{mL}$ ). A porcine insulin powder was dissolved in PBS with $1 \mathrm{M} \mathrm{HCl}$
(pH 8.0 adjusted with $\mathrm{NaOH}$ ). It was then diluted with PBS to obtain desired concentration in $\mathrm{mg} / \mathrm{mL}$. All hormonal treatments used a concentration of $1 \mu \mathrm{g}$ per female.

\section{RNA extraction, cDNA synthesis, and qPCR}

RNA extraction and cDNA preparation followed a method described in Al Baki et al. [27]. Estimation of gene expression levels used qPCR under the guideline of Bustin et al. [69]. PCR conditions were described in Al Baki et al. [27] using forward and reverse primers (Additional file 5: Table S2). Expression of $\beta$-actin was used as reference because of its relatively stable expression in different tissues of $M$. vitrata [70]. Quantitative analysis was performed using the comparative CT $\left(2^{-\Delta \Delta C T}\right)$ method [71]. All qPCRs were replicated three times using independent biological samples.

\section{Fluorescence microscopic analysis}

Ovaries from 5 days old virgin females were collected in PBS and separated into ovarioles. Ovarioles were then fixed with $3.7 \%$ paraformaldehyde in a wet chamber under darkness at room temperature (RT) for $60 \mathrm{~min}$. After washing three times with PBS, cells in ovarioles were permeabilized with $0.2 \%$ Triton $\mathrm{X}-100$ in PBS at RT for $20 \mathrm{~min}$. Cells were then washed three times in PBS and blocked with 5\% skim milk (MB cell, Seoul, Korea) in PBS at RT for $60 \mathrm{~min}$. After washing once with PBS, ovarian cells were incubated with FITC-tagged phalloidin in PBS at RT for $1 \mathrm{~h}$. After washing three times with PBS, cells were incubated with DAPI $(1 \mathrm{mg}$ / $\mathrm{mL}$ ) diluted 1000 times in PBS at RT for $2 \mathrm{~min}$ for nucleus staining. After washing three times in PBS, ovarian cells were observed under a fluorescence microscope (DM2500, Leica, Wetzlar, Germany) at 200x magnification.

\section{In vitro organ culture and BrdU incorporation}

For in vitro organ culture, ovaries from 5 days old virgin females were collected and cultured in TC-100 insect cell culture medium (Hyclone, Daegu, Korea) containing $10 \mu \mathrm{M}$ BrdU (Sigma-Aldrich, Seoul, Korea) for $24 \mathrm{~h}$ at $25^{\circ} \mathrm{C}$. These ovaries were then fixed, permeabilized, and blocked by the methods described above. After washing ovaries with PBS, cells were incubated with mouse antiBrdU antibody (BD Bioscience, San Jose, CA, USA) diluted 1:15 in blocking solution for $1 \mathrm{~h}$. After washing three times in PBS, the ovary was then incubated with FITC-conjugated anti-mouse antibody (Sigma-Aldrich, Spruce street, St. Louis, USA) diluted 1:300 in blocking solution at RT for $1 \mathrm{~h}$. After washing three times with PBS, cells were stained with DAPI as described above. These ovarian cells were then observed under the fluorescence microscope. 


\section{SDS-PAGE for vg analysis}

Tissues were collected for 10\% SDS-PAGE analysis. L5 larval hemolymph was collected and the plasma was separated by centrifugation at $200 \times g$ for $3 \mathrm{~min}$. Virgin females and males at 5 days old were selected and used to extract hemolymph and reproductive organs. Hemolymph was collected by PBS injection to adult hemocoel and subsequent suction. These hemolymph samples were then centrifuged at $200 \times \mathrm{g}$ for $3 \mathrm{~min}$ to obtain supernatant plasma. Ovaries and testes were collected by dissection of female and male adults, respectively. Reproductive organs were then ground in PBS and centrifuged at $14,000 \times \mathrm{g}$ for $3 \mathrm{~min}$ to obtain supernatants. All protein samples were quantified by Bradford [72] assay. Each $100 \mu \mathrm{g}$ protein sample was loaded to $10 \%$ SDS-PAGE. After gel running at $125 \mathrm{~V}$ constant, separated protein bands were stained with Coomassie brilliant blue and destained with mixture of $50 \%$ methanol and $10 \%$ acetic acid for $2 \mathrm{~h}$.

\section{Liquid chromatography-tandem mass (LC-MS/MS) analysis} To confirm Vg from females, its corresponding protein band in molecular size was excised and sent to a proteomic analysis center of Genomine Inc. (Pohang, Korea). After in-gel digestion, the resulting tryptic peptides were analyzed using reversed phase HPLC coupled to an ion trap mass spectrometer (LC-MS/MS) (LCQ Deca XP Plus, Thermo Finnigan, San Jose, CA, USA) using a method of Zuo et al. [73]. Individual spectra from MS/ MS were processed using TurboSEQUEST software (Thermo Quest). Generated peak list files were used to query NCBI using MASCOT program (https://pfam. xfam.org). Protein identification used MASCOT probability analysis at scores above 50 .

\section{Statistical analysis}

All results were expressed as mean \pm standard deviation and plotted using Sigma plot (Systat Software, San Jose, CA, USA). Means were compared by least square difference (LSD) test of one-way analysis of variance (ANOVA) using PROC GLM of SAS program [74] and discriminated at Type I error $=0.05$.

\section{Abbreviations}

20E: 20-hydroxyecdysone; Akt: Serine-threonine protein kinase;

$\mathrm{CH}$ : Chorionated; FA: Farnesoic acid; FOXO: Forkhead Box O; IIS: Insulin/ insulin-like growth factor signal; ILP: Insulin-like peptide; InR: Insulin receptor; IPC: Insulin-producing cell; JH: Juvenile hormone; PV: Previtellogenic; TOR: Target of rapamycin; Vg: Vitellogenin; VgR: Vitellogenin receptor; $\mathrm{VT}$ : Vitellogenic

\section{Additional files}

Additional file 1: Figure S1. Oocyte development of $M$. vitrata. Ovaries from 5 days old virgin female were collected and their ovarioles were separated. Newly dividing cells were specifically recognized by BrdU incorporation (green) while nucleus was stained with DAPI (blue). Cells were observed under a fluorescence microscope. (A) Distal germarial area containing terminal filament and stem cell niche at 200x magnification. (B) Mid-germarial area showing non-oocyte (NOC) and oocyte (OC) at 200x magnification. (C) Proximal germarial area showing previtellogenic oocytes surrounded by follicular epithelium (FE) at 400x magnification. Nurse cells (NC) are neighboring to oocytes (asterisk), indicating polytrophic ovarioles of M. vitrata. (TIF $5952 \mathrm{~kb}$ )

Additional file 2: Figure S2. Domain (A) and phylogenetic (B) analyses of vitellogenin $(\mathrm{Vg})$ of $\mathrm{M}$. vitrata. Domains were predicted by Pfam (https://pfam.xfam.org), including Vg amino terminal ( $\mathrm{Vg}-\mathrm{N})$, domain of unknown function (DUF 1943), and von willebrand factor type D (VWD). Amino acid sequences of $\mathrm{Vg}$ were retrieved from GenBank with the following accession numbers: XP_013168895.1 for Papilio xuthus, XP_021195456.1 for Helicoverpa armigera, NP_001037309.1 for Bombyx mori, XP_022836548.1 for Spodoptera litura, AOH73254.1 for Spodoptera exigua, XP_011555415.1 for Plutella xylostella, XP_971398.1 for Tribolium castaneum, XP_006616039.1 for Apis dorsata, XP_003492277.1 for Bombus impatiens, and MG799570 for Maruca vitrata. Amino acids were aligned with ClustalW. Phylogenetic analysis was performed using MEGA6. Bootstrapping values were obtained with 1000 repetitions to support branch and clustering. (DOCX $340 \mathrm{~kb}$ )

Additional file 3: Figure S3. Domain (A) and phylogenetic (B) analyses of vitellogenin receptor $(\mathrm{VgR})$ of $M$. vitrata. Domains were predicted by Pfam (https://www.pfam.xfam.org/), including LDL receptor (LR) and calcium binding EGF (EGF). Amino acid sequences of vitellogenin receptor $(\mathrm{VgR})$ were retrieved from GenBank with the following accession numbers: XP_013181939.1 for Papilio xuthus, AGF33811.2 for Helicoverpa armigera, XP_022818502.1 for Spodoptera litura, AOX13593.1 for Spodoptera exigua, NP_001184180.1 for Bombyx mori, XP_022125502.1 for Pieris rapae, XP_011564499.1 for Plutella xylostella, AAC28497.1 for Aedes aegypti, XP_016767970.1 for Apis mellifera, XP_019847160.1 for Bactrocera dorsalis, and MG799569 for M. vitrata. Amino acids were aligned with ClustalW and phylogenetic analysis was performed using MEGA6. Bootstrapping values were obtained with 1000 repetitions to support branch and clustering. (DOCX $383 \mathrm{~kb}$ )

Additional file 4: Table S1. Diet treatment and nutrient composition. (DOCX $15 \mathrm{~kb}$ )

Additional file 5: Table S2. Primers used in this study for RT-qPCR. (DOCX $16 \mathrm{~kb}$ )

\section{Acknowledgements}

We appreciate Youngim Song for supplying materials and treating researchassociated administration.

Authors' contributions

YK conceived and designed the experiments. AAB performed the experiments. $Y K$ and $A A B$ analyzed the data. YK, AAB, DL, and JKJ wrote the paper. All authors read and approved the final manuscript.

\section{Funding}

This study was supported by an Agenda Research Grant (Project number: PJ01182001) funded by the Rural Development Administration, Republic of Korea. This funding agency had no input on the design of the studies and the collection, analysis and interpretation of the data. It also had no input on the writing of the manuscript.

\section{Availability of data and materials}

Sequence data supporting the conclusions of this article are included within the article and its additional files. Four dsRNAs specific to IIS component genes are available from YK upon request.

Ethics approval and consent to participate Not applicable.

Consent for publication Not applicable. 


\section{Competing interests}

The authors declare that they have no competing interests.

\section{Author details}

'Department of Plant Medicals, Andong National University, Andong 36729, Korea. ${ }^{2}$ School of Chemistry and Life Sciences, Kyungsung University, Busan 48434, Korea. ${ }^{3}$ Division of Crop Cultivation and Environment Research, Department of Central Area Crop Science, National Institute of Crop Science, Rural Development Administration, Suwon 16429, Korea.

Received: 26 October 2018 Accepted: 17 June 2019 Published online: 05 July 2019

\section{References}

1. Engel MS. Insect evolution. Curr Biol. 2015;25:R868-72.

2. Heinze J, Schrempf A. Aging and reproduction in social insects-a minireview. Gerontology. 2008:54:160-7.

3. Büning J. The insect ovary: ultrastructure, previtellogenic growth and evolution. London: Chapman \& Hall; 1994.

4. Telfer W, Anderson L. Functional transformations accompanying the initiation of a terminal growth phase in the cecropia moth oocyte. Dev Biol. 1968;17:512-35.

5. McLaughlin JM, Bratu DP. Drosophila melanogaster oogenesis: An Overview. Methods Mol Biol. 2015;1328:1-20.

6. Davey KG, Sevala VL, Prestwich GD, Jurd LL. Antagonists and agonists of JH action on the follicle cells of Locusta migratoria. In: Borkovec AB, Loeb MJ, editors. Insect neurochemistry and neurophysiology 1993. Boca Raton: CRC Press; 1994. p. 285-8.

7. Sappington TW, Raikhel AS. Molecular characteristics of insect vitellogenesis and vitellogenin. Insect Biochem Mol Biol. 1998:28:277-300.

8. Ramaswamy SB, Mbata GN, Cohen NE. Necessity of juvenile hormone for choriogenesis in the moth, Heliothis virescens (Noctuidae). Invert Reprod Dev. 1990;17:27-33.

9. Roy S, Saha TT, Zou Z, Raikhel AS. Regulatory pathways controlling female insect reproduction. Annu Rev Entomol. 2018;63:489-511.

10. Jindra M, Palli SR, Riddiford LM. The juvenile hormone signaling pathway in insect development. Annu Rev Entomol. 2013;58:181-204.

11. Jindra M, Bellés $X$, Shinoda T. Molecular basis of juvenile hormone signaling. Curr Opin Insect Sci. 2015;11:39-46.

12. Guo W, Wu Z, Yang L, Cai Z, Zhao L, Zhou S. Juvenile hormone-dependent Kazal-type serine protease inhibitor Greglin safeguards insect vitellogenesis and egg production. FASEB J. 2019;33:917-27.

13. Riddiford LM. Cellular and molecular actions of juvenile hormone. I. General considerations and premetamorphic actions. Adv Insect Physiol. 1994;24: 213-74.

14. Wu Z, Guo W, Yang L, He Q, Zhou S. Juvenile hormone promotes locust fat body cell polyploidization and vitellogenesis by activating the transcription of Cdk6 and E2f1. Insect Biochem Mol Biol. 2018:102:1-10.

15. Satyanarayana K, Bradfield JY, Bhasharan G, Dahm KH. Stimulation of vitellogenin production by methoprene in prepupae and pupae of Manduca sexta. Arch Insect Biochem Physiol. 1994;25:21-37.

16. Wyatt GR, Davey KG. Cellular and molecular actions of juvenile hormone. II. Roles of juvenile hormone in adult insects. Adv Insect Physiol. 1996;26:1-155.

17. Martín D, Wang SF, Raikhel AS. The vitellogenin gene of the mosquito Aedes aegypti is a direct target of ecdysteroid receptor. Mol Cell Endocrinol. 2001; 173:75-86.

18. Oberlander H, Silhacek DL, Porcheron P. Non-steroidal ecdysteroid agonists: tools for the study of hormonal action. Arch Insect Biochem Physiol. 1995; 28:209-23.

19. Jing $Y P, A n H$, Zhang $S$, Wang $N$, Zhou S. Protein kinase $C$ mediates juvenile hormone-dependent phosphorylation of $\mathrm{Na}+/ \mathrm{K}+-\mathrm{ATP}$ ase to induce ovarian follicular patency for yolk protein uptake. J Biol Chem. 2018;293:20112-22.

20. Kim $Y$, Davari ED, Sevala V, Davey KG. Functional binding of a vertebrate hormone, $L-3,5,3^{\prime}$-triiodothyronine $\left(T_{3}\right)$, on insect follicle cell membranes. Insect Biochem Mol Biol. 1999:29:943-50.

21. Sevala VL, Davey KG. Action of juvenile hormone on the follicle cells of Rhodnius prolixus: evidence for a novel regulatory mechanism involving protein kinase C. Experientia. 1989;45:355-6.

22. Wu Q, Brown MR. Signaling and function of insulin-like peptides in insects Annu Rev Entomol. 2006;51:1-24.
23. Spradling AC. Developmental genetics of oogenesis. In: Bate M, Martinez Arias A, editors. The development of Drosophila melanogaster. Cold Spring Harbor: Cold Spring Harbor Laboratory Press; 1993. p. 1-70.

24. Badisco L, Wielendaele PV, Vanden Broeck J. Eat to reproduce: a key role for the insulin signaling pathway in adult insects. Front Physiol. 2013;4:202.

25. Richard DS, Rybczynski R, Wilson TG, Wang Y, Wayne ML, Zhou Y, Partridge L, Harshman LG. Insulin signaling is necessary for vitellogenesis in Drosophila melanogaster independent of the roles of juvenile hormone and ecdysteroids: female sterility of the chico ${ }^{7}$ insulin signaling mutation is autonomous to the ovary. J Insect Physiol. 2005;51:455-64.

26. Das D, Arur S. Conserved insulin signaling in the regulation of oocyte growth, development, and maturation. Mol Reprod Dev. 2017;84:444-59.

27. Al Baki MA, Jung JK, Maharjan R, Yi H, Ahn JJ, Gu X, Kim Y. Application of insulin signaling to predict insect growth rate in Maruca vitrata (Lepidoptera: Crambidae). PLoS One. 2018:13:e0204935.

28. Oldham $\mathrm{S}$, Hafen E. Insulin/IGF and target of rapamycin signaling: a TOR de force in growth control. Trends Cell Biol. 2003;13:79-85.

29. Sharma HC. Bionomics, host plant resistance, and management of the legume pod borer, Maruca vitrata - a review. Crop Prot. 1998;17:373-86.

30. Feng B, Qian K, Du YJ. Floral volatiles from Vigna unquiculata are olfactory and gustatory stimulants for oviposition by the bean pod borer moth Maruca vitrata. Insects. 2017;8:60

31. Kambysellis MP, Heed WB. Studies of oogenesis in natural populations of Drosophilidae. I. Relation of ovarian development and ecological habitats of the Hawaiian species. Am Nat. 1971;105:31-49.

32. Roitberg BD, Boivin G, Vet LEM. Fitness, parasitoids, and biological control: an opinion. Can Entomol. 2001;133:429-38.

33. Smykal V, Raikhel AS. Nutritional control of insect reproduction. Curr Opin Insect Sci. 2015;11:31-8.

34. Al Baki MA, Jung JK, Kim Y. Regulation of hemolymph trehalose titers by insulin signaling in the legume pod borer, Maruca vitrata (Lepidoptera: Crambidae). Peptides. 2018;106:28-36.

35. Han C, Chen E, Shen G, Peng Z, Xu Y, Zhang H, Liu H, Zhang Y, Wu J, Lin Y, Xia Q. Vitellogenin receptor selectively endocytoses female-specific and highly-expressed hemolymph proteins in the silkworm, Bombyx mori. Biochem Cell Biol. 2017:95:510-6.

36. Chandrayudu E, Srinivasan S, Rao NV. Comparative biology of spotted pod borer, Maruca vitrata (Geyer) in major grain legumes. J Appl Zool Res. 2005; 16:147-9.

37. Zhao J, Sun Y, Xiao L, Tan Y, Jiang Y, Bai L. Vitellogenin and vitellogenin receptor gene expression profiles in Spodoptera exigua are related to host plant suitability. Pest Manag Sci. 2018;74:950-8.

38. Géminard C, Rullifson EJ, Leopold P. Remote control of insulin secretion by fat body cells in Drosophila. Cell Metab. 2009:10:199-207.

39. Hansen IA, Attardo GM, Rodriguez SD, Drake LL. Four-way regulation of mosquito yolk protein precursor genes by juvenile hormone-, ecdysone-, nutrient-, and insulin-like peptide signaling pathways. Front Physiol. 2014;5:103.

40. Bellés X. Endocrine effectors in insect vitellogenesis. In: Coast GM, Webster SG, editors. Recent advances in arthropod endocrinology. Cambridge: Cambridge University Press; 1998. p. 68-90.

41. Nijhout HF. Insect hormones. Princeton: Princeton University Press; 1994

42. Ramaswamy SB, Shengqiang S, Park YI, Zeng F. Dynamics of juvenile hormone-mediated gonadotropism in the Lepidoptera. Arch Insect Biochem Physiol. 1997:35:539-58.

43. Onishi E. Growth and maturation of ovaries in isolated abdomens of Bombyx mori: response to ecdysteroids and other steroids. Zool Sci. 1987:4:315-21.

44. Furusawa T, Narutaki A, Mitsuda K, Teramoto N. Stage dependent limited degradation of vitellin and its localization in the Japanese oak silkworm, Antheraea yamamai, during embryonic development. Comp Biochem Physiol. 1993;104B:787-94.

45. Davis RE, Kelly TJ, Masler EP, Fescemyer HW, Thyagaraja BS, Borkovec AB. Hormonal control of vitellogenesis in the gypsy moth, Lymantria dispar (L.): suppression of haemolymph vitellogenin by the juvenile hormone analogue methoprene. J Insect Physiol. 1990;36:231-8.

46. Feycemyer HW, Masler EP, Davis RE, Kelly TJ. Vitellogenin synthesis in female larvae of the gypsy moth, Lymantria dispar (L.): suppression by juvenile hormone. Comp Biochem Physiol. 1992;103B:533-42.

47. Hiremath $\mathrm{S}$, Jones $\mathrm{D}$. Juvenile hormone regulation of vitellogenin in the gypsy moth, Lymantria dispar-suppression of vitellogenin messenger RNA in the fat body. J Insect Physiol. 1992;38:461-74. 
48. Shirk PD, Zimowska G, Silhacek DL, Shaaya E. Initiation of vitellogenesis in pharate adult females of the Indianmeal moth, Plodia interpunctella. Arch Insect Biochem Physiol. 1992;21:53-63.

49. Zeng F, Shu S, Park YI, Ramaswamy SB. Vitellogenin and egg production in the moth, Heliothis virescens. Arch Insect Biochem Physiol. 1997;34:287-300.

50. Satyanarayana K, Bhaskaran G, Dahm KH, Meola R. Regulation of vitellogenin synthesis by juvenile hormone in the corn earworm, Helicoverpa zea. Invertebr Reprod Dev. 1992;21:169-78.

51. Benz G. The stimulation of oogenesis in Pieris brassicae by the juvenile hormone derivative farnesoic acid ethyl ester. Experientia. 1970;26:1012.

52. Herman WS, Bennet DC. Regulation of oogenesis, female specific protein production, and male and female reproductive gland development by juvenile hormone in the butterfly, Nymphalis antiopa. J Comp Physiol. 1975; 99:321-38.

53. Pan ML, Wyatt GR. Control of vitellogenin synthesis in the monarch butterfly by juvenile hormone. Dev Biol. 1976;54:127-34.

54. Herman WS, Dallman SH. Endocrine biology of the painted lady butterfly, Vanessa cardui. J Insect Physiol. 1981;27:163-8.

55. Bohla RK, Sarna S. Juvenile hormone induced vitellogenin synthesis in Danaus chrysippus (Insecta: Lepidoptera). Naturalia. 1990;15:47-55.

56. Cusson M, Yu CG, Carruthers K, Wyatt GR, Tobe SS, McNeil JN. Regulation of vitellogenin production in armyworm moths, Pseudaletia unipuncta. J Insect Physiol. 1994;40:129-36.

57. Sorge D, Nauen R, Range S, Hoffmann KH. Regulation of vitellogenesis in the fall armyworm, Spodoptera frugiperda (Lepidoptera: Noctuidae). J Insect Physiol. 2000;46:969-76.

58. Schooley DA, Baker FC, Tsai LW, Miller CA, Jamieson GC. Juvenile hormones 0, I and II exist only in Lepidoptera. In: Hoffmann J, Porchet M, editors. Biosynthesis, metabolism and mode of action of invertebrate hormones. Berlin: Springer; 1984. p. 371-83.

59. Kim Y, Kim D, Lee J. Disturbance of adult eclosion by fenoxycarb, a juvenile hormone mimic, in the beet armyworm, Spodoptera exigua. J Asia Pac Entomol. 2000;3:103-11.

60. Zheng YP, Sugie H, Tojo S. Juvenile hormone titre and hormonal regulation of storage protein synthesis in the common cutworm, Spodoptera litura. Entomol Sci. 2000:3:9-18.

61. Drummond-Barbosa D, Spradling AC. Stem cells and their progeny respond to nutritional changes during Drosophila oogenesis. Dev Biol. 2001;231:265-78.

62. Shim J, Gururaja-Rao S, Banerjee U. Nutritional regulation of stem and progenitor cells in Drosophila. Development. 2013;140:4647-56.

63. Tatar M, Kopelman A, Epstein D, Tu MP, Yin CM, Garofalo RS. A mutant Drosophila insulin receptor homolog that extends life-span and impairs neuroendocrine function. Science. 2001;292:107-10.

64. Böhni R, Riesgo-Escovar J, Oldham S, Brogiolo W, Stocker H, Andruss BF, Beckingham K, Hafen E. Autonomous control of cell and organ size by CHICO, a Drosophila homolog of vertebrate IRS1-4. Cell. 1999;97:865-75.

65. Tu MP, Yin CM, Tatar M. Mutations in insulin signaling pathway alter juvenile hormone synthesis in Drosophila melanogaster. Gen Comp Endocrinol. 2005;142:347-56.

66. Brown MR, Clark KD, Gulia M, Zhao Z, Garczynski SF, Crim JW, Suderman RJ, Strand MR. An insulin-like peptide regulates egg maturation and metabolism in the mosquito Aedes aegypti. Proc Natl Acad Sci U S A. 2008; 105:5716-21.

67. Santos CG, Humann FC, Hartfelder K. Juvenile hormone signaling in insect oogenesis. Curr Opin Insect Sci. 2019;31:43-8.

68. Jung JK, Seo BY, Cho CR, Kwon YH, Kim GH. 2009. Occurrence of lepidopteran insect pests and injury aspects in adzuki bean fields. Korean J Appl Entomol. 2009;48:29-35.

69. Bustin SA, Benes V, Garson JA, Hellemans J, Huggett J, Kubista M, Mueller R, Nolan T, Pfaffl MW, Shipley GL, Vandesompele J, Wittwer CT. The MIQE guidelines: minimum information for publication of quantitative real-time PCR experiments. Clin Chem. 2009;55:4.

70. Chang JC, Ramasamy S. Identification and expression analysis of diapause hormone and pheromone biosynthesis activating neuropeptide (DH-PBAN) in the legume pod borer, Maruca vitrata Fabricius. PLoS One. 2014;9:e84916.

71. Livak KJ, Schmittgen TD. Analysis of relative gene expression data using real-time quantitative PCR and the $2^{-\Delta \Delta C T}$ method. Methods. 2001;25:402-8.

72. Bradford MM. A rapid and sensitive method for the quantitation of microgram quantities of protein utilizing the principle of protein-dye finding. Anal Biochem. 1972;72:248-54.
73. Zuo X, Echan L, Hembach P, Tang HY, Speicher KD, Santoli D, Speicher DW. Towards global analysis of mammalian proteomes using sample prefractionation prior to narrow $\mathrm{pH}$ range two dimensional gels and using one-dimensional gels for insoluble and large proteins. Electrophoresis. 2001; 22:1603-15.

74. SAS Institute. SAS/STAT user's guide. Cary: SAS Institute, Inc.; 1989.

\section{Publisher's Note}

Springer Nature remains neutral with regard to jurisdictional claims in published maps and institutional affiliations.
Ready to submit your research? Choose BMC and benefit from:

- fast, convenient online submission

- thorough peer review by experienced researchers in your field

- rapid publication on acceptance

- support for research data, including large and complex data types

- gold Open Access which fosters wider collaboration and increased citations

- maximum visibility for your research: over $100 \mathrm{M}$ website views per year

At $\mathrm{BMC}$, research is always in progress.

Learn more biomedcentral.com/submissions 